\title{
Serials Management In Polytechnic Libraries in Nigeria: A Comparative Study of Kaduna Polytechnic And Yaba College of Technology Libraries
}

\author{
BY \\ Thomas Adubika \\ College Library Yaba College Of Technology Yaba - Lagos \\ Solaadubi@yahoo Co. UK
}

\begin{abstract}
Despite the strategic position of serials publications amongst the materials acquired in the library most especially academic libraries and in spite of their unique values as dependable allies of academics and other researchers and the increasing cost of their acquisition, the management of serials has not enjoyed a corresponding attention from library managers as well as writers in the field of librarianship. Investigation was therefore conducted to appraise serials management practices in two polytechnic libraries. Attention was directed at such specific routines as selection and acquisition of serials, recording of titles, methods of serials dissemination, filling of gaps in back runs, binding of serials and other issues that are considered most crucial in serials management. Solutions were proffered to identified problems.
\end{abstract}

\section{Introduction}

Libraries generally, but most particularly the academic genre are universally acknowledged as the central focus of any educational enterprise. They are usually referred to as the "heart" of knowledge. This global characterization is borne out of the pride of place and the prominent roles they play in the lives of their parent institutions. Infact, kwampong (1970) captured the views of most enthusiasts when he described the library as the heart and aorta of any academic institution. He said the health, intellectual vitality and the effectiveness of any educational institution depends in the main on the state of health and excellence of its library, which is its very lifeblood. An inert and moribund library, he further opines will ultimately translate into an inert and moribund institution.

This category of libraries which are mostly found in the universities, polytechnics, colleges of education and other institutions of higher learning play very crucial roles towards the attainment of the overall objectives of their parent institutions. Quality faculty and indeed quality education may be difficult not impossible to achieve in the absence of a quality library. In other words, without a good library, an educational institution can be considered dead in terms of knowledge generation, acquisition and dissemination. It is not surprising therefore that the library is a foremost requirement in the setting up of tertiary Institutions worldwide

The main functions of institutions of higher learning (Universities, Polytechnics, colleges of education) are conservation of knowledge and ideas, research, teaching, publication, extension or community service. In collaboration with their peers anywhere around the globes, they are also expected to advance the frontiers of knowledge. The major obligation of the library in this regard according to Olanlokun and Salisu (1993) is to provide information resources and services that will contribute to the effective performance of these functions through -

(a) Collection of all media of information.

(b) Organization of knowledge for easy storage and retrieval.

(c) Storage and preservation of knowledge for the use of posterity and

(d) Retrieval and dissemination of knowledge.

In other words, the academic library exists within an organizational framework that is defined by the shapes of the parent institution. This means that the library is not an autonomous entity. It should therefore be responsive to the environment of which it is part. The content and services of the library should be focused on the programmes offered by the institution and on the needs of the faculty and students. In a nutshell, the mission of the academic library is to acquire information, organize it, preserve it and make it readily available at the point of need .Apart from books, there exists a vast amount of publishing in serials form, which over the years has assumed a pride of place as dependable allies of the researcher most especially in the academic environment. But what is a serial?

A serial in the words of Harolds (1987) is any publication bearing either chronological or numerical designation issued in successive parts appearing at intervals (usually regular ones) and as a rule intended to be continued indefinitely. The Anglo-American cataloguing Rules (AACR) of 1988 revised in Nisonger (1988) on its part defines a serial as a publication in any medium issued in successive parts bearing numeric or chronological designations and intended to be continued indefinitely. Serials publications include periodicals, newspapers, magazines, journals, memoirs, proceedings, transactions of professional associations and numbered monographic series. They vary in formats and in frequency of publication such as daily, weekly, monthly, 
quarterly, biannually, annually or irregularly. Serials publications must not be confused with SERIES which is a book consisting of parts or volumes published successively with a common title and intended to be continued indefinitely but not necessarily at regular, intervals as is normally the case with serials. Periodicity that is the quality of being regularly recurrent therefore is an essential feature of serial publications. A serial can also assume the format of a paper, microfiche, on-line or CD-Rom.

Serial publications represent a most important reference source not only because of their sizes but also because they present other numerous values, which the book medium fails to offer. Perhaps their greatest value lies in the fact that they provide the newest and most nearly up-to-date information. Apart from announcing scientific discoveries and serving as avenues for the publication of scientific researches, research-in-progress, they are also a safeguard to researcher for sifting through the maze of irrelevant materials in their search for the relevant ones. And so where recency of information is of prime consideration, the serials have a distinct advantage over the book. The time lag involved in the publication of serials in usually shorter. They take only a few months to publish whereas it takes a much longer duration (in some cases years) to publish in book form. The fact about an important scientific discovery appears for example in the newspapers, the day it is announced. The events discussed in news magazines seldom have occurred more than a week before the date of publications. Articles that appear in scholarly journals are perhaps often written a few weeks before publication. Serial publications have therefore become an important source of reference materials whenever the subject in which one is dealing is likely to be affected by new discovered or relent events.

\section{Review of Literature}

Amaakaven (1995) defines serials management as the formulation of routines and procedures for administering serials collection. These routines include such functions as selection and acquisition, recording of serials, cataloguing and classification, dissemination of Journals, handling of claims, renewals of subscriptions, weeding, filling gaps in backrooms, treatment of unbound issues, preparation for binding and policy for binding back issues. The management of serials according to Nisoger (1988) is probably the most important and most challenging serials function. Interests in serials management he contends has increased in recent years due to such factors as escalating cost of serials in face of stagnant or decreasing library budgets, the emergence of new electronic formats and an increased emphasis on access rather than ownership.

Farrington (1998) examined issues influencing serials ownership such as ownership /Access, outsourcing of cataloguing, document delivery and electronic texts. He also provided an overview and some background for all of the trends and topics that serials managers must know about in order to be prepared for changes in the academic serials environment

Nisonger (2000) on his part explored the use of journal citation reports for journal management in academic libraries. He listed both the advantages and the disadvantages of using journal citation reports data and researches the impact of journal self-citation on journal citation reports ranking of library and information science and genetics Cook (2002) in his attempt to refresh and acquaint practitioners who need to become familiar with issues odf collection management, Serials records function and preservation, highlighted key issues such as evaluation and revision of policy statements, guidelines for reviewing subscriptions and standing orders, criteria for cancellation/renewals, retention decisions, weeding selection of print serials off-site or high density storage, cataloguing and processing priorities, selecting titles for minimal level cataloguing and issues relating to the emerging explosion of electronic serials.

Kyrillidou (2003) in a two decade statistical analysis of serials global trends reported that serials unit costs increased by $215 \%$. According to her reports, the average cost of a serial subscription for Association of Research Libraries which was $\$ 89.77$ in 1983 rose to $\$ 283$ by 2003 . In a similar vein, the unit cost for books during the same period covered by her survey also rose by $82 \%$ from an average of $\$ 28$ to $\$ 52$.

Betterton and Wade (2001) in their study of serial management (print and e-journal) in the learning centre of Sheffield Hallam University examined traditional areas of serial management namely, Budget Management, Selection Criteria, Bibliographic Information and General Collection Management. Their study also proffered solutions to current challenges information professionals face in providing access to serial information.

\section{Statement of the Problem}

Due to their peculiar nature, serial publications are usually expensive both in terms of subscription and maintenance cost. Academic libraries commit a most substantial percentage of their annual budgets to Journal subscription. Davidson (1969) in Amaakaven (1995) averred that it is not unusual to find libraries committing as much as two-third of 
their annual budgets to serials acquisition. Their sources of supply, bibliographic control as well as acquisition practices are not the same as those for monographic publications hence the need for proper management, most especially in the academic library environment where serials form a most important source of information to the researcher. In spite of the unique value of serials and the very important roles they play in the operations of academic libraries, serials management has not enjoyed corresponding attention from library managers as well as writers in the field of library and information science. This often results in poor management of serials collection which further results in loss of serials, existence of gaps in the collection and many other irregularities, the most frustrating of which is unmet requests. It is not unusual to witness a scenario where library patrons are unable to access serials which the library is known to have subscribed. In most cases, no satisfactory explanation could be offered for this parlous state of affairs. The frustration of most researchers caught in this kind of dilemma can therefore be better Imagined.

Against the background of the foregoing, It is therefore necessary to pay special attention to how academic libraries most especially polytechnic libraries can maximize the acquisition and use of their serials to the greatest benefit of their diverse and sophisticated clientele both now and in the future .In other words, the emergence of serials as an effective tool in modern information and research have called for serials managers with indepth knowledge of their peculiarity and Techniques for controlling them.

\section{Scope and Limitation}

This study compares serials management in two polytechnics - Yaba College of Technology and Kaduna Polytechnic Libraries. It is specifically limited to the following aspects of serials management:

(a) Selection and acquisition of new serials titles

(b) Recording of incoming serials

(c) Dissemination of serials

(d) Retrieval of materials from the shelves

(e) Preparation for binding and

(f) Policy for binding back issues.

These areas constitute the pivot on which serials management revolves. How well they are handled determines to a large extent the library's efficiency and effectiveness in terms of meeting the needs of users. Further more, the two institutions aside from being first generation polytechnics with similar socio-economic characteristics in terms of ownership, funding, students enrolment and the size of their collection, the diversity of courses offered in both institutions have made them ready reference points for other polytechnics in Nigeria and therefore suited for this kind of study.

\section{Methodology}

The data for the study were collected in June 2006, through the use of questionnaires. The questionnaire was designed to elicit information on the respective libraries serials management policy as it relates to selection and acquisition of serials titles, recording of in-coming Journals, and retrieval of materials from the shelves, preparation of materials for binding and policy for binding back issues. In addition, the researcher also had some interactive sessions with the serials librarians of the institutions where some gray areas not addressed by the questionnaire were clarified. All administered questionnaire were dully completed by the heads of the Libraries and the serials librarians of both institutions. The high response rate was made possible because the questionnaire were self-administered by the researcher who also made several repeated visits to observe the operations of the serials departments of the institutions and also to collect completed questionnaires.

\section{Discussion of Findings}

Both libraries give adequate attention to the selection of core Journals. Also, referred to as foundation journals, Core Journals are the most useful journals in the various fields of study in courses offered in the institutions. Most of the titles selected are those analyzed in the indexing and abstracting services. Although selection of serials in the two libraries under investigation is not restricted to the serials librarians alone, the degree of participation varies. For instance, at the Yaba College of Technology, the serials librarian and his assistants do selection. The polytechnic librarian also participates very actively in serials selection. Apart from Heads of other divisions in the Library, academic Staff and Students in some cases are expected to send in lists of suggested titles for subscription to the serials librarian who collates all requests, scrutinize them before sending them to the polytechnic librarian for final vetting.

At the Kaduna Polytechnic Library, the selection function is limited to the polytechnic librarian, the serials librarian and heads of academic departments in the Institution. Staff requests for serials subscription are usually channeled to the serials librarian through the heads of departments. Thus, the Yaba College of Technology allows a wider range of participation in serials selection as it involves academic non-academic and even students in some instances. 
Both libraries acquire their serials through direct purchase from the open market and also through publishers and subscription agents. While agents handle foreign titles, local publishers handle the local titles on their lists. The Yaba College of Technology Library has embraced the CD-ROM Technology in its efforts at serving its users with current Journals. The library subscribes to EBSCO Journal of academic Publishing, which covers all fields of human endeavor, most especially in courses offered in the institution. The Total Serials holdings of Yaba College of Technology as at the time of investigation stand at 18,125 volumes. Out of this number, 15,000 or $83.9 \%$ are current titles, while 3125 or $16.1 \%$ are Back-runs. Also, Gifts and Exchange account for 5000 or $27.58 \%$ of the total serial holdings of the library.

The study also revealed that the, Kaduna Polytechnic library has a total serials holding of 10,050 volumes. 20 titles or $0.20 \%$ are current while 10,030 or $99.8 \%$ are Back issues. Gifts are exchange account for $0.29 \%$ or 30 volumes. The disparity in the serials holding of the two libraries may be attributed to the differences not only in the age but also in the courses offered in the two institutions. The Yaba College of Technology was established in 1948. It is presently structured into seven (7) schools with 33 academic departments. The Kaduna Polytechnic on the other hand was established in 1968. At the moment, it has four colleges, seven schools and 29 Academic departments.

As regards currency of serials titles, the Yaba College of Technology library stock more current tittles. This is made possible through the library's huge investment in the CD-ROM Technology. Library users are allowed to copy desired issues of it EBSCO journal of Academic Publishing at reduced cost.

In-coming serials in Yaba College of Technology library are sorted and recorded using three main tools. These are the Kardex, Daily arrival Register and the Accessions lists. The Arrival register records on a daily basis all serials received in the library before the actual entry is made on the Kardex card. The cards have provision for recording the title, call number frequency of serials number per volume per year publisher and address, subscription cost and agent's address. The system of recording in-coming serials at the Kaduna Polytechnic library is slightly different, from practices at the Yaba College of Technology library. The Accessions lists and the Daily Arrival Register (Notebook) are the only tools used in recording serials thus, the practices in both libraries conform with the American library Association guidelines for recording serials which states interalia that

(i) Libraries should accurate records of orders receipts and Payments. This record is usually maintained by means of some forms of visible file arranged by main entry.

(ii) It usually includes Bibliographic Data such as entry history and

Frequency as well as records of issues received, payments made and claims sent along with order number and source of supply.

(iii) A record of the date of receipt of each issue should be maintained.

Even though, the two libraries adopt a slightly different pattern in recording in-coming serials, the details contained, in these records meet the requirements of the American Library Association quoted above.

Table 1 Organisational Structure of Kaduna Polytechnic and Yaba College of Technology

\begin{tabular}{|l|l|l|l|l|}
\hline $\begin{array}{l}\text { Name of } \\
\text { Institution }\end{array}$ & $\begin{array}{l}\text { Year of } \\
\text { Establishment }\end{array}$ & $\begin{array}{l}\text { No of } \\
\text { Schools }\end{array}$ & $\begin{array}{l}\text { No of } \\
\text { Colleges }\end{array}$ & $\begin{array}{l}\text { Academic } \\
\text { Departments }\end{array}$ \\
\hline $\begin{array}{l}\text { Kaduna } \\
\text { Polytechnic }\end{array}$ & 1968 & 7 & 4 & 29 \\
\hline $\begin{array}{l}\text { Yaba } \\
\begin{array}{l}\text { College of } \\
\text { Technology }\end{array}\end{array}$ & 1947 & 7 & - & 33 \\
\hline
\end{tabular}

Table 2---Serial Holding of Kaduna Polytechnic and Yaba College of Technology

\begin{tabular}{|l|l|l|l|ll|}
\hline $\begin{array}{l}\text { Name of } \\
\text { Institution }\end{array}$ & $\begin{array}{l}\text { Total } \\
\text { Serial } \\
\text { Holdings }\end{array}$ & $\begin{array}{l}\text { Current } \\
\text { Titles }\end{array}$ & $\begin{array}{l}\text { Back- } \\
\text { Issues }\end{array}$ & Gifts/Exchange \\
\hline $\begin{array}{l}\text { Kaduna } \\
\text { Polytecnic }\end{array}$ & 10,050 & $\begin{array}{l}20 \text { or } \\
0.2 \%\end{array}$ & $\begin{array}{l}10,030 \\
\text { or } \\
98 \%\end{array}$ & 30 or $0.29 \%$ & \\
\hline $\begin{array}{l}\text { Yaba } \\
\begin{array}{l}\text { College of } \\
\text { Technology }\end{array}\end{array}$ & 18,125 & $\begin{array}{l}15000 \\
\text { or } 83 \%\end{array}$ & $\begin{array}{l}3125 \\
\text { or } \\
16.1 \%\end{array}$ & $\begin{array}{l}5000 \\
27.58 \%\end{array}$ & or \\
\hline
\end{tabular}

The Yaba College of Technology library, do not catalogue their serials. In place of cataloguing, the library however maintains a stripdex, which is regularly updated to reflect the library serials holdings. At the Kaduna Polytechnic library, an integrated catalogue with books is maintained. The library also prepares a separate serials list for users. This has helped to reduce overcrowding at the catalogue area with other users wishing to accessbooks. Although, integrating a serials catalogue with books could be cumbersome and very inconvenient in an academic library with a sizeable collection, the practice however has the advantage of describing fully, the subject matter of the serials through analytical cataloguing.

Serials are classified in both libraries through the same classification scheme - The Dewey Decimal Classification scheme. At the Yaba College of 
Technology library, the serials librarian or any other professional librarian in the section classify the first issues of all serials. Subsequent additions are then assigned their appropriate call number by paraprofessionals. At the Kaduna Polytechnic Library, serials classification is done both by professional librarians and experienced paraprofessionals.

The study reveals that the two libraries employ different methods to disseminate their serials titles. The First method common to both libraries is by display. At the Yaba College of Technology Library current titles are displayed on the open shelves in a classified order. Within the classes, the Journals are arranged alphabetically by title. At the Kaduna Polytechnic Library on the other hand, current titles are displayed alongside with books on related subjects while back issues are withdrawn from the shelves and kept in closed access. Other serials dissemination methods employed, by both libraries include compilation and distribution of lists of new serials titles added to the stock, routing of new Journals to officers, borrowing and circulation of table of contents of new acquisitions to relevant departments in both institutions.

Both Libraries withdraw volumes of serials from current shelves once they are complete. In both cases, the withdrawn volumes are shelved in closed access in a classified order and labeled accordingly. From the closed access serials are then prepared for Binding. At the Yaba College of Technology Library a comprehensive list of materials for binding is prepared in triplicate, while at the Kaduna Polytechnic the prepared list is in duplicates. Both libraries send one, copy of the list along with the consignment to the Bindery and keep one for the records. However the third copy in Yaba College of Technology Library is kept to answer enquiries from both staff and students. The list gives the title, the call number, Accessions number, Volume number and year of publication of each Journal listed. These details facilitate crosschecking when the Journals are finally bound and returned to the library.

At the Yaba college of Technology library, all compete and in-complete volumes are bound. This is to forestall any loss that may occur should the incomplete volumes be left unbound. This practice however contrasts with what obtains at the kaduna polytechnic where only the complete volumes are bound. All incomplete volumes are tied in their separate volumes with the necessary information on the number of issues that are missing. Both libraries in the past bound all the Daily Newspapers received in the library on a monthly basis. This practice for some years has been discontinued probably due to dwindling finance given to both libraries which may have also accounted for the reduction in the number of Daily Newspapers subscribed to by both libraries. While the Yaba College of Technology library subscribes to seven (7) Newspapers, the Kaduna Polytechnic Library receives Eight (8) Newspapers Daily

\section{Conclusion}

In the light of the findings from this study, it can be said that both the Yaba College of Technology Library and its Kaduna Polytechnic counterpart to a significant extent follow established procedures for managing serials collections. In the selection and acquisition of serials, the various programmes of their institutions guide both libraries. They also give special attention to the basic or core journals in all the fields of study in their respective institutions. The acquired titles are those that are analyzed in the major indexing and abstracting services.

Both libraries record their serials accurately and timely. However, the Yaba College of Technology Library employs more instruments (Daily Arrival Register, Kardex and Accessions lists) than the Kaduna Polytechnic Library (Accession lists, Arrival Register) while the Yaba College of Technology Library maintain the serials collection through the stripdex, the Kaduna Polytechnic Library employs an integrated catalogue in which both books are serials are catalogued in one alphabetical sequence.

Both libraries face a common problem of inadequate funding, which have resulted in their inability to pay for new titles and to renew old subscription. The Yaba College of Technology Library has however found a way out by investing in the CD-ROM Technology.

\section{Recommendations}

The Kaduna Polytechnic Library and indeed other polytechnic libraries in the country should explore ways of embracing the CD-ROM Technology as a panacea to problem of outdated serials. The whole polytechnics in Nigeria can form a consortium and assign specific fields to members and then share the acquired resources amongst themselves.

The libraries should also take advantage of a host of foreign sponsors who are ready to fund specific areas of focus e.g. serials acquisition. But the libraries must be ready to justify such sponsorship through their proposals

\section{References}

Ammakaven F.G. (1995) Comparative study of serials management in Kashim Ibrahim library and the University of Jos. Unpublished (MLS) Thesis. 
Betterton Ann and Wade Airleen (2001) Issues about access: Serial Information in an Academic context. Information Services and Use 21 (3-4) 123-130

Cook Eleanor (2002) Serials acquisitions and management in academic and research libraries: Implication for quality library services. Information services and use 9 (3) $161-170$

Farrington, J.W (2000) Serials Management in Academic Libraries: A guide to issues and practices. London: Greenwood press, 192pp]

Harrod, L.M. (1987) Harrods Librarian glossary of terms used in Librarianship documentation and the bookcrafts and reference. Books $6^{\text {th }}$ ed. Aldershot Hans: Gower P. 426

Kwapong, A (1970) Library Education “an address to Ghana library. Association Ghana Library Journal 4 (19) 42.

Kyrillidou (2003) Serials acquisitions and cost. The serial librarian 2(3) 16-25

Nisonger, T.E. (1988) Management of serials in Libraries. Engle wood:Libraries unlimited, inc. P.1

Olanlokun S.O. and Salisu. T.M (1993) Understanding the library: A hand Book on library use. Lagos: University of Lagos press p. 25. 